\title{
PROSIDING
}

\section{Seminar Kontribusi Fisika 2014}

http://portal.fi.itb.ac.id/skf20I4

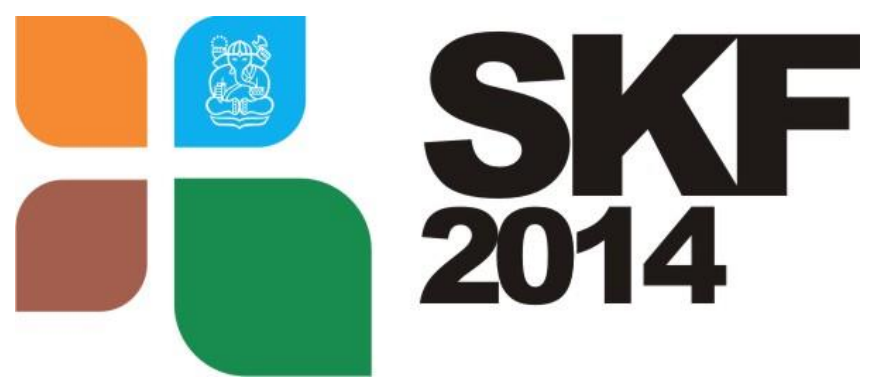

ISBN : 978-602-19655-7-3

Editor : Fiki Taufik Akbar, Agus Suroso, Dwi Irwanto, Triati Dewi Kencana Wungu, Syeilendra Pramuditya

(C) 2015

Penerbit :

Program Studi Magister Pengajaran Fisika

Fakultas Matematika dan Ilmu Pengetahuan Alam

Institut Teknologi Bandung

Jl. Ganesha no. 10 Bandung 


\title{
Analisis Capaian Kompetensi Guru Bidang Studi Fisika pada Pelaksanaan Sertifikasi Guru dalam Jabatan Tahun 2013 di Provinsi Maluku Utara
}

\author{
Saprudin \\ Email: Saprudin unkhair@yahoo.com
}

\begin{abstract}
Abstrak
Penelitian ini merupakan penelitian deskriptif yang bertujuan untuk menggambarkan profil kompetensi guru bidang studi fisika yang mengikuti sertifikasi guru dalam jabatan tahun 2013 pada PSG Rayon 130 Universitas Khairun. Data-data dikumpulkan melalui studi dokumentasi yakni dokumen hasil UKA dan UTN peserta PLPG bidang studi fisika. Pengolahan data dilakukan secara deskriptif kuantitatif. Berdasarkan hasil analisis data disimpulkan bahwa; 1) profil kompetensi guru fisika sebelum mengikuti PLPG tahun 2013 dikategorikan rendah $(25,6), 2)$ profil kompetensi guru fisika setelah mengikuti PLPG dikategorikan cukup $(55,0), 3)$ Secara umum terjadi peningkatan kompetensi guru bidang studi fisika setelah mengikuti PLPG tahun 2013.
\end{abstract}

Kata-kata kunci: Sertifikasi, UKA, UTN

\section{Pendahuluan}

Sertifikasi merupakan proses pemberian sertifikat pendidik kepada guru yang telah memenuhi persyaratan tertentu yakni memiliki kualifikasi akademik, kompetensi, sehat jasmani dan rohani serta memiliki kemampuan untuk mewujudkan pendidikan nasional yang dibarengi dengan peningkatan kesejahteraan yang layak [1].

Tahun 2013, jumlah kuota peserta sertifikasi guru dalam jabatan pada Rayon 130 Universitas Khairun sebanyak 1609 peserta dengan rincian seperti pada Tabel 1.

Tabel 1. Rekapitulasi Peserta Sertifikasi Guru Kuota Tahun 2013

\begin{tabular}{clc} 
No & Kabupaten & Jumlah \\
\hline 1 & Kab. Halmahera Tengah & 91 \\
2 & Kab. Halmahera Barat & 219 \\
3 & Kab. Halmahera Utara & 198 \\
4 & Kab. Halmahera Selatan & 237 \\
5 & Kab. Halmahera Timur & 91 \\
6 & Kab. Kepulauan Sula & 267 \\
7 & Kab. Morotai & 65 \\
8 & Kota Ternate & 300 \\
9 & Kota Tidore Kepulauan & 141 \\
TOTAL & $\mathbf{1 6 0 9}$ \\
\hline
\end{tabular}

[2]
Terkait bidang studi fisika, jumlah peserta yang mengikuti sertifikasi pada Rayon 130 Universitas Khairun tahun 2013 adalah sebanyak 17 guru dengan rincian seperti pada Tabel 2.

Tabel 2. Rekapitulasi Peserta Sertifikasi Guru Bidang Studi Fisika Kuota Tahun 2013

\begin{tabular}{clc} 
No & Kabupaten & Jumlah \\
\hline 1 & Kab. Halmahera Tengah & 1 \\
2 & Kab. Halmahera Barat & 4 \\
3 & Kab. Halmahera Timur & 1 \\
4 & Kab. Kepulauan Sula & 2 \\
5 & Kota Ternate & 6 \\
6 & Kota Tidore Kepulauan & 3 \\
TOTAL & $\mathbf{1 7}$ \\
\hline
\end{tabular}

[2]

Mulai tahun 2012 atau tahun keenam sertifiksi guru dalam jabatan, dilaksanakan kebijakan yang cukup mendasar dalam penyelenggaraan sertifikasi guru yaitu Uji Kompetesi Awal (UKA) sebagai persyaratan bagi guru yang sertifikasinya mengikuti pola PLPG. Pada akhir PLPG dilakukan uji kompetensi yang meliputi uji tulis dan uji kinerja (ujian praktik). Ujian tulis bertujuan untuk mengungkap kompetensi profesional dan pedagogik, sedangkan ujian kinerja untuk mengungkap kompetensi profesional, pedagogik, kepribadian, dan sosial secara holistik [3]. 
Dalam penelitian ini, uji kompetensi akhir yang dijadikan pembanding terhadap Uji Kompetensi Awal (UKA) adalah Ujian Tulis Nasional (UTN) yang soal ujiannya dikembangkan secara nasional di bawah koordinasi KSG. Hasil uji kompetensi ini, dapat dijadikan sebagai acuan untuk menganalisis capaian kompetensi guru khususnya guru bidang studi fisika.

Berdasarkan uraian di atas, maka sangat penting dilakukan analisis capaian kompetensi guru di provinsi Maluku Utara sehingga dapat ditelusuri secara akurat mengenai gambaran kompetensi guru di Maluku Utara. Gambaran tentang capaian komptensi tersebut, diharapkan para pengambil kebijakan untuk memberikan tindakan yang akurat dalam meningkatkan mutu dan kompetensi guru di Maluku Utara secara signifikan khususnya bagi guru bidang studi fisika.

\section{Teori}

Undang-undang RI Nomor 20 Tahun 2003 tentang Sistem Pendidikan Nasional, Undangundang RI Nomor 14 Tahun 2005 tentang Guru dan Dosen, Peraturan Pemerintah RI Nomor 19 Tahun 2005 tentang Standar Nasional Pendidikan, dan Peraturan Pemerintah RI Nomor 74 Tahun 2008 Tentang Guru menyatakan guru adalah pendidik profesional. Guru yang dimaksud meliputi guru kelas, guru mata pelajaran, dan guru bimbingan dan konseling atau konselor. Guru profesional dipersyaratkan memiliki kualifikasi akademik yang relevan dengan mata pelajaran yang diampu dan menguasai kompetensi sebagaimana dituntut oleh Undang undang Guru dan Dosen. Pengakuan guru sebagai pendidik profesional dibuktikan dengan sertifikat pendidik yang diperoleh melalui suatu proses sistematik yang disebut sertifikasi [3].

Sertifikasi bagi guru dalam jabatan sebagai salah satu upaya peningkatan mutu guru diharapkan dapat meningkatkan mutu pendidikan pada satuan pendidikan formal secara berkelanjutan. Guru dalam jabatan yang telah memenuhi persyaratan dapat mengikuti sertifikasi melalui: 1) Pemberian Sertifikat Pendidik secara Langsung, 2) Portofolio, 3) Pendidikan dan Latihan Profesi Guru atau 4) Pendidikan Profesi Guru [3].

Pendidikan dan Latihan Profesi Guru (PLPG) merupakan salah satu pola dalam pelaksanaan sertifikasi guru dalam jabatan tahun 2013 yang bertujuan untuk meningkatkan kompetensi, profesionalisme, dan menentukan kelulusan guru peserta sertifikasi [3].
Kompetensi guru merupakan seperangkat pengetahuan, keterampilan dan perilaku yang harus dimiliki, dihayati, dikuasai dan diwujudkan oleh guru dalam melaksanakan tugas keprofesionalannya [4].

Dalam UU Guru dan Dosen Nomor 14 tahun 2005 tentang guru dan dosen pasal 1 ayat 10 disebutkan bahwa kompetensi adalah seperangkat pengetahuan, keterampilan dan perilaku yang harus dimiliki, dihayati dan dikuasai oleh guru atau dosen dalam melaksanakan keprofesionalan" [5]. Dalam Undang-undang tersebut dinyatakan juga bahwa kompetensi guru meliputi kompetensi kepribadian, pedagogik, professional dan kompetensi sosial.

\section{Metode}

Jenis penelitain ini merupakan penelitian deskriptif. Populasi dalam penelitian ini adalah seluruh guru yang mengikuti PLPG pada sertifikasi guru tahun 2013 di provinsi maluku utara. Sedangkan sampel dalam penelitian ini adalah guru bidang studi fisika di provinsi Maluku Utara yang mengikuti PLPG pada sertifikasi guru tahun 2013. Pengumpulan data dilakukan dengan studi dokumentasi nilai UKA (Uji Kompetensi awal) dan UTN (Ujian Tulis Nasional). Teknik analisis data dilakukan secara deskriptif kuantitatif.

\section{Hasil dan diskusi}

\section{Profil Kompetensi Guru Bidang Studi Fisika Pada Pelaksanaan Sertifikasi Tahun 2013}

Profil Kompetensi Guru bidang studi fisika sebelum dan sesudah mengikuti PLPG tahun 2013 pada Rayon 130 Universitas Khairun dapat ditunjukkan pada gambar 1 .

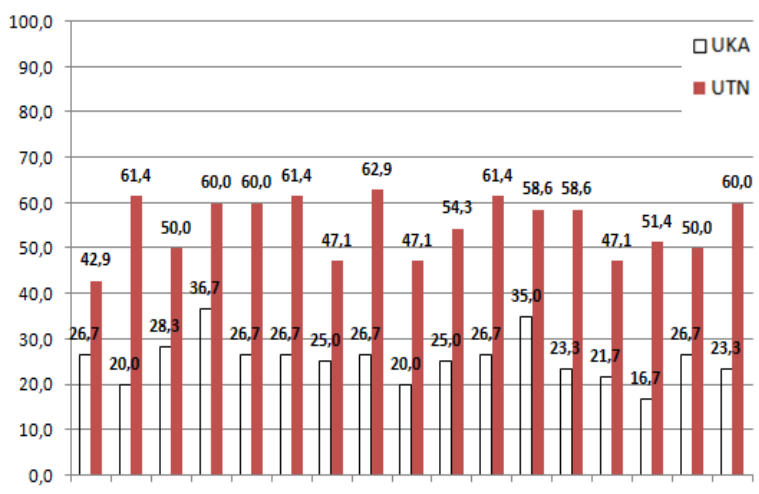

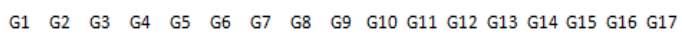

Kategori : Sangat Rendah $=0-20$, Rendah $=20-40$,

Cukup $=40-60$, Baik $=60-80$, Sangat Baik $=80-100$

Gambar 2. Profil Kompetensi Guru Bidang Studi Fisika pada Pelaksanaan Sertifikasi Guru dalam Jabatan Tahun 2013 di Rayon 130 Unkhair 
Berdasarkan gambar 1, secara umum kompetensi guru bidang studi Fisika sebelum mengikuti PLPG tahun 2013 dikategorikan rendah $(25,6)$, sedangkan setelah mengikuti PLPG dikategorikan cukup $(55,0)$.

\section{Dampak PLPG tahun 2013 terhadap Peningkatan Kompetensi Guru Bidang Studi Fisika di Provinsi Maluku Utara}

Kompetensi guru bidang studi Fisika di provinsi Maluku Utara dapat ditelusuri dari skor UKA (Uji Kompetensi Awal) dan UTN (Ujian Tulis Nasional). Untuk melihat besarnya peningkatan kompetensi guru, kita dapat menentukan besarnya gain skor ternormalisasi ( $\mathrm{N}$-gain). Adapun untuk lebih jelasnya besarnya gain skor ternormalisasi untuk setiap guru dapat dilihat pada Tabel 3.

Tabel 3. Peningkatan Kompetensi Guru Fisika di Provinsi Maluku Utara Setelah Mengikuti PLPG Tahun 2013

\begin{tabular}{ccccc}
\hline Guru & UKA & UTN & N-gain & Kategori \\
\hline G1 & 26,7 & 42,9 & 0,22 & Rendah \\
G2 & 20,0 & 61,4 & 0,52 & Sedang \\
G3 & 28,3 & 50,0 & 0,30 & Sedang \\
G4 & 36,7 & 60,0 & 0,37 & Sedang \\
G5 & 26,7 & 60,0 & 0,45 & Sedang \\
G6 & 26,7 & 61,4 & 0,47 & Sedang \\
G7 & 25,0 & 47,1 & 0,30 & Sedang \\
G8 & 26,7 & 62,9 & 0,49 & Sedang \\
G9 & 20,0 & 47,1 & 0,34 & Sedang \\
G10 & 25,0 & 54,3 & 0,39 & Sedang \\
G11 & 26,7 & 61,4 & 0,47 & Sedang \\
G12 & 35,0 & 58,6 & 0,36 & Sedang \\
G13 & 23,3 & 58,6 & 0,46 & Sedang \\
G14 & 21,7 & 47,1 & 0,33 & Sedang \\
G15 & 16,7 & 51,4 & 0,42 & Sedang \\
G16 & 26,7 & 50,0 & 0,32 & Sedang \\
G17 & 23,3 & 60,0 & 0,48 & Sedang \\
Rerata & $\mathbf{2 5 , 6}$ & $\mathbf{5 5 , 0}$ & $\mathbf{0 , 3 9}$ & Sedang \\
\hline
\end{tabular}

Berdasarkan tabel 3, dapat ditunjukkan bahwa adanya PLPG tahun 2013 dapat meningkatkan kompetensi guru bidang studi fisika di provinsi Maluku utara. Besarnya peningkatan kompetensi guru fisika setelah mengikuti PLPG tahun 2013 dapat dikategorikan sedang $(\mathrm{N}$-gain $=0,39)$.

\section{Kesimpulan}

Berdasarkan hasil penelitian dan analisis data, maka dapat disimpulkan sebagai berikut;

1. Profil kompetensi guru bidang studi fisika di Provinsi Maluku Utara sebelum mengikuti PLPG pada sertifikasi guru dalam jabatan tahun 2013 dapat dikategorikan rendah $(25,6)$.
2. Profil kompetensi guru bidang studi fisika di Provinsi Maluku Utara sesudah mengikuti PLPG pada sertifikasi guru dalam jabatan tahun 2013 dapat dikategorikan cukup $(55,0)$.

3. Secara umum terjadi peningkatan kompetensi guru bidang studi fisika pada pelaksanaan PLPG tahun 2013. Peningkatan kompetensi tersebut dapat dikategorikan sedang $(\mathrm{N}$-gain $=0,39)$

\section{Ucapan terima kasih}

Penulis mengucapkan terima kasih kepada : Ketua Rayon, Ketua Pelaksana dan juga Divisi Data PSG Rayon 130 Universitas Khairun.

\section{Referensi}

[1] Muslich M, Sertifikasi Guru Menuju Profesionalisme Pendidik, Jakarta, Bumi Aksara, 2007

[2] PSG Rayon 130 Universitas Khairun, Laporan Pelaksanaan Sertifikasi Guru dalam Jabatan Tahun 2013. PSG Rayon 130 Universitas Khairun, tidak diterbitkan

[3] Kemdikbud, Badan Pengembangan Sumber Daya Manusia Pendidikan Kebudayaan dan Penjaminan Mutu pendidikan, SERTIFIKASI GURU DALAM JABATAN TAHUN 2013 (BUKU 4) Ramburambu Pelaksanaan Pendidikan dan Latihan Profesi Guru (PLPG), Kemdikbud. 2013

[4] Sarimaya Farida, Sertifikasi Guru (Apa, Mengapa dan Bagaimana). Bandung, Yrama Widya, 2009

[5] Sagala Syaiful. Kemampuan Profesional Guru dan Tenaga Kependidikan. Bandung, Alfabeta, 2009

\section{Saprudin *}

Divisi Data PSG Rayon 130

Universitas Khairun

Saprudin_unkhair@yahoo.com

${ }^{*}$ Corresponding author 